\title{
Who wants to conserve remaining forest fragments in the Manompana corridor?
}

\author{
Zora L. Urech', Hans R. Felber"' and Jean-Pierre Sorg'
}

Correspondence:

Zora L. Urech

Groupe de foresterie pour le développement, Department for Environmental Sciences, ETH Zurich, Zurich, Switzerland E-mail: urechz@gmail.com

nature que les milieux scientifiques essayent d'endiguer la déforestation. Depuis les années 1996 la politique nationale à Madagascar a généré lois et processus visant à transférer la gestion des ressources forestières de l'Etat aux communautés locales. Cependant, il n'a pas été possible, jusqu'à ce jour, d'atténuer l'ampleur de la destruction et de la fragmentation des forêts pluviales de l'île. Plus encore, à I'heure actuelle la perception de l'importance des fragments de forêts n'est pas connue par la population. Un projet de recherche a été lancé pour contribuer à combler cette lacune, dans le corridor de Manompana, sur la côte. Les buts de ce projet étaient (i) d'explorer l'importance des fragments de forêts pour les revenus monétaires de la population locale et (ii) d'analyser la perception de l'importance des fragments de forêts par la population locale. Les recherches se sont déroulées dans quatre villages situés à des distances différentes du grand massif forestier. La population locale a été répartie en différentes catégories de niveau de vie et en fonction de la distance à parcourir entre les villages et la forêt. Cette approche a permis d'étudier le rôle de la forêt quant aux revenus monétaires des différents groupes de la population. Nous avons également cherché à établir un lien entre l'ampleur des revenus monétaires et un intérêt à conserver les fragments de forêts qui subsistent. Nos méthodes de recherche font recours à des exercices de " scoring ", à des discussions avec des groupes ciblés et à des enquêtes de ménages. II ressort des analyses que certains groupes ont un intérêt à conserver les fragments forestiers. Cet intérêt est significativement lié, d'une part, au niveau de vie de la population, d'autre part, à la distance entre le village et le massif forestier. Cependant, l'intérêt à conserver les fragments de forêts est plus fortement lié à la conscience de la finitude des ressources forestières qu'au montant des revenus monétaires que la population peut tirer des produits forestiers.

\section{INTRODUCTION}

The planet is gradually losing its original tropical forests (Shvidenko et al. 2008). Most tropical landscapes are not only confronted with severe deforestation but also with forest fragplan global, aussi bien les organisations de protection de la 
mentation (Laurance et al. 1998, Ranta et al. 1998, Laurance et al. 2002), which often leads to decreasing vitality of remaining contiguous forests (Malanson and Armstrong 1996, Shvidenko et al. 2008). This is also the case in Madagascar, where forests are increasingly fragmented (Harper et al. 2007, Gorenflo et al. 2011) by agricultural activities (Messerli 2002, Pollini 2009). Between 1950 and 2000 more than $40 \%$ of the island's forests were cleared, and between 2000 and 2005 the annual deforestation rate was estimated to be $0.5 \%$ (USAID 2009), resulting in a patchwork of dispersed forest fragments (Harper et al. 2007). Forest fragments are of growing importance, not only for the biodiversity, but also for the well-being (Pfund et al. 2006, Bawa et al. 2007). Rural people are increasingly forced to meet their needs by taking products from the remaining forest fragments (Pfund 2000). In the Manompana corridor, on the eastern coast of Madagascar, people have to walk large distances to reach larger contiguous forests. Thus, they collect forest products for daily life in the forest fragments that are closer to villages. These products, such as fuel wood, timber, medicinal plants, honey, tubers and others, seem to be important for the local population and their livelihood (Fedele et al. 2011, Urech et al. 2011). Despite the apparent importance of forest fragments, forest clearance in Manompana is continuing (Pfund et al. 2011).

With this research we aimed to identify population groups who might be interested in preserving the remaining forest fragments of Manompana. Various studies have shown that a population's dependence on forest resources can influence its interest in conserving these resources (e.g., Gibson 2001). Following Ostrom (1999), people's interest in conserving forest remains low as long as populations do not place strong importance on the forest for their daily livelihoods. Another hypothesis states that with the awareness about the growing scarcity of resources, the interest in conserving them will grow (Behera 2009, Wu and Mweemba 2010). Based on these hypotheses we pursued three research objectives: (i) to develop a methodology that would measure the importance of forest fragments and forest massif for local people's life; (ii) to analyze whether or not people's dependence on forest resources has an influence on their conservation interest; and (iii) to assess what influence resource scarcity has on people's interest in forest fragment conservation. This knowledge should help future communitybased forest management projects in the region to meet the differing interests coming from the rural inhabitants and to consider individual perceptions.

\section{METHODOLOGY}

RESEARCH AREA. Our research area, the Manompana corridor, is located on the east coast of Madagascar in the region of Analanjirofo, district Soanierana-Ivongo (Figure 1). The area of about 50,000 ha extends over three communes and about 30,000 ha of the landscape are covered by natural forest (Rakotomavo 2009). We worked in four villages situated around the large contiguous forest (Table 1). The villages Ambofampana and Maromitety are situated near the forest massif in very remote and inaccessible areas. To reach the closest small market via road or a river, villagers have to walk six to eight hours. The villages Bevalaina and Antsahabe are less remote but far from the massif in a territory where only forest fragments remain and the next market is reachable in one to two walking hours. In this region and its 30,000 ha of forests, a community-

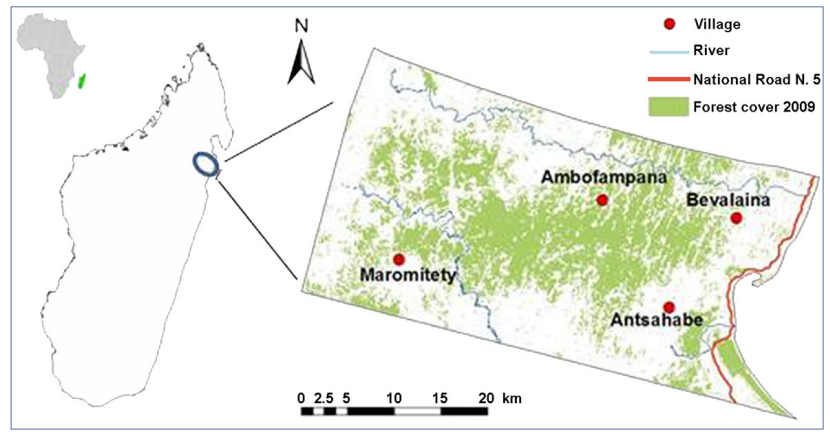

FIGURE 1. Study site with the four analysed villages (data source: KoloAla Manompana 2009)

based forest management project has recently been implemented. With decentralized management legislation, based on the GELOSE principle (Bertrand et al. 2006), the local population receives the right to beneficial but sustainable management of forest resource.

THE DEFINITION OF FOREST FRAGMENT AND FOREST

MASSIF. The forest of our study site is classified as evergreen lowland rainforest (Moat and Smith 2007) and is in a continuous process of fragmentation. Nevertheless, it still remains a large part of a contiguous natural forest, which we label 'the forest massif' (Legout et al. 2008, Urech et al. 2011). This forest massif is surrounded by a belt of forest fragments, caused by agricultural activities of the local population such as slash-and-burn cultivation (Harper et al. 2007). Aiming to understand the particular role of forest fragments, we separated all natural forests into forest massifs and forest fragments. In the current literature, there are different definitions for fragments based on differing sizes and shapes (e.g., Laurance et al. 1998, ODEM 2005, Martin 2008). We defined fragments based on a combination of both, current research theories and local understanding. For example, a small forest that is surrounded by agricultural fields and that is still partly connected to the massif would be, following the local understanding, a fragment. Following the definitions of shape and size this forest would be considered as a part of a massif. Considering local understanding is crucial for this research, we aimed especially to comprehend local practices, perceptions and interests. To identify forest cover by satellite image interpretation, a definition of forest fragments and massif was developed by Rabenilalana (2011), based on ODEM (2005). As a result, the whole contiguous natural forest, including larger forest patches of more than 500 ha, has been classified as a forest massif. All natural forests smaller than 500 ha, surrounded by agricultural land or fallows and therefore not connected to the massif are considered forest fragments. Forest cover was identified by satellite image interpretation (Rabenilalana et al. 2010) using LANDSAT-images from the year 2009.

CATEGORIZATION OF HOUSEHOLDS. Aiming to analyze which population groups depend most on forest resources and which may be the most interested in forest conservation, we categorized all households into groups.

The categorization of distance to the forest massif: One categorization relates to forest resource scarcity, which can influence peoples' behavior and thinking (Rustagi et al. 2010). The analysis of forest cover indicates scarcity of forest resources increases with distance from the forest massif. We therefore grouped all villages into two categories of near ( $\leq 0.5$ hours walking time) and far (> 0.5 hour walking time) from the forest 
massif. For the categorization, we measured the walking time from the village to the nearest edge of the forest massif guided by local farmers. The distance to the forest massif correlates negatively with the distance to markets (Spearman's correlation, $r=-0.933, n=106, p<0.001)$.

The categorization of wealth: Following other studies wealth has an influence on the dependency on forest resources (Barham et al. 1999, Wunder 2001, Dubois 2003, Tumusiime et al. 2011). Therefore, we separated all households into three categories of wealth: wealthier, intermediate and poor. The criteria for the different wealth levels have been adapted to our region and were the same for all villages. Criteria were based on household characteristics such as land property, livestock, crop diversity, quality of house construction, dependency on day labor and alternative income possibilities, as well as on the household's social status in the village (Gaemperli 1997, Schmidt 2007, Carter 2008).

INTERVIEW AND SCORING EXERCISES. A multi-method

research approach (Ormsby and Kaplin 2005) was adopted to gain a broad understanding of peoples' perceptions and interests, based on open-discussions, semi-structured household interviews and scoring exercises with focus groups. Open discussions ( $\mathrm{N}=20$ ) with randomly selected households helped to get a general overview of the relation between villagers and natural forests (opportunities, rules, risks, traditional use, etc.) and to respond to villagers' misgivings and queries with regard to our research activities. Semi-structured household interviews $(\mathrm{N}=110)$ were conducted to collect data about the most important forest products (timber and non-timber forest products (NTFPS)), quantitative yields, and qualitative information about the general use of resources as well as about conservation interests.

To assess how the local population judges the importance of different landscape types and products coming from forests, we applied scoring exercises (Sheil and Liswanti 2006, Sheil et al. 2006). Relative judgements of importance should be subjective and depend on personal experiences (Sheil et al. 2002) and not be expressed in terms of prices and quantities. Exercises were conducted in each village with groups of five people, separated by wealth levels (poor, intermediate, wealthier) and gender (two groups per wealth level) ( $N=120,6$ groups in 4 villages). The number of five participants allowed for statistical representativeness but also discussions and exchange among villagers. To express their own judgment of importance, each group had to distribute 100 pebbles on nine different landscape types (defined by the participants, see Table 2) according to their value. Each group had to repeat the distribution of the pebbles for eight different categories of goods and products (Table 3), which ultimately totaled 800 distributed pebbles.

ASSESSING DEPENDENCY BASED ON CASH INCOME.

All people living within the research area depend on forest resources (e.g., for house construction and fuel wood). However,
TABLE 2. Categories of landscape types.

\begin{tabular}{|l|l|l|}
\hline Landscape types & Categories & Definition \\
\hline $\begin{array}{l}\text { Irrigated rice } \\
\text { fields }\end{array}$ & Uncultivated & Water and riverside \\
\hline Tavy & Agriculture & $\begin{array}{l}\text { Irrigated, permanent rice fields } \\
\text { other products on slopes after } \\
\text { slash-and-burn }\end{array}$ \\
\hline Savoka & Uncultivated & $\begin{array}{l}\text { Secondary vegetation after tavy, } \\
\text { not cultivated }\end{array}$ \\
\hline Marsh & Uncultivated & $\begin{array}{l}\text { Wet and periodically or } \\
\text { permanently flooded ground }\end{array}$ \\
\hline Fragments & Natural forest & $\begin{array}{l}\text { Permanent natural tree cover } \\
\text { connected to the forest massif }\end{array}$ \\
\hline Village garden & Agroforestry & $\begin{array}{l}\text { Trees and plants cultivated in the } \\
\text { village around the houses }\end{array}$ \\
\hline Tanimboly & Agroforestry & $\begin{array}{l}\text { Traditional agroforestry system } \\
\text { with a combination of trees and } \\
\text { annual crops }\end{array}$ \\
\hline
\end{tabular}

only some farmers rely on a supplementary cash income earned from forest products. Especially during lean periods, before the harvest season when rice is becoming scarce, households are strongly dependent on an alternative income to buy additional provisions (Razafy 2004, Minten and Barrett 2008). During such periods, logging and timber transport, as well as the trade of NTFPs such as honey and handicrafts made from Pandanus guillaumetii (Fedele et al. 2011), become fundamental sources for alternative income. Therefore, income from forest products was considered to be the most important variable to assess the dependence of the different population groups on forest resources.

DATA ANALYSIS. Cash income generation from

forest resources: To explore possible factors that could influence the cash income from forest resources, we considered two independent variables: distance to the forests massif and wealth level. Dependent variables were cash income from raw timber, cash income from NTFPS (mainly honey, handicraft from Pandanus guillaumetii), and total cash income from forest resources (timber \& NTFPS). Statistical analysis was conducted applying the non-parametric Kruskall-Wallis test.

Relative judgment of the importance of natural forests: To explore the factors that could influence the relative judgment of forest importance, we used two independent variables, wealth and distance to the forest massif. We then tested the influence of wealth and distance to the forest massif on the dependent variables: (i) importance of forest fragments for income (including both, timber and NTFPS), (ii) importance of forest massif for income (including both, timber and NTFPS), and (iii) importance of the total natural forest (including both, fragment and massif) for income (including both, timber and NTFPS). For statistical

TABLE 1. Village characteristics in terms of distance to the forest massif, forest cover (Rabenilalana 2011) and market proximity.

\begin{tabular}{|l|c|c|c|}
\hline Village characteristics & Ambofampana & Maromitety & Antsahabe \\
\hline Distance to forest massif [walking time in h] & 0.25 & 0.5 & near \\
\hline Category of distance to forest massif & near & 75 & far \\
\hline Forest cover [\% of total village territory] & 86 & 20 & 43 \\
\hline Forest fragments [\% of forest in village territory] & 5 & 8 & 100 \\
\hline Market proximity [walking time in h] & 6 & 100 \\
\hline
\end{tabular}


TABLE 3. Categories of goods and products.

\begin{tabular}{|l|l|}
\hline Categories & Definition \\
\hline Food & Plants, products or animals which can be eaten \\
\hline Medicine & Natural products used for medicine and health \\
\hline House construction & Materials to build houses \\
\hline Tools & $\begin{array}{l}\text { Materials to build tools for agriculture, hunting, } \\
\text { fishery }\end{array}$ \\
\hline Fire wood & Fuel \\
\hline Weaving & $\begin{array}{l}\text { Plants used for weaving products, such as mats, } \\
\text { hats, baskets }\end{array}$ \\
\hline Cash income & $\begin{array}{l}\text { Cash income generation by products which can } \\
\text { be sold (crops, NTFP, timber, handicrafts) }\end{array}$ \\
\hline Hunting and fishing & \begin{tabular}{l} 
Animals (lemurs, tenrecs, fish etc.) \\
\hline
\end{tabular}
\end{tabular}

analysis we used the non-parametric Mann-Whitney-U and Kruskall-Wallis tests.

Conservation interest: To explore the relationship between the categories of wealth and distance and the villagers' responses regarding forest conservation, the spearman corre-

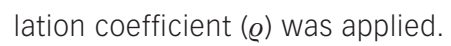

\section{RESULTS}

DIFFERENCE BETWEEN THE IMPORTANCE OF FOREST

MASSIF AND FOREST FRAGMENTS. In order to determine the relative importance of forest massifs and forest fragments, we compared how the villages rated their importance regarding the distance of each village from the forest massif. When rated in comparison to other landscape types (including all eight categories of goods and products), forest massifs have been assigned the highest score in the two villages near the massif (Ambofampana and Maromitety), and forest fragments received the highest score for the two villages far from the massif (Bevalaina and Antsahabe) (Table 4). However, forests play a role in almost all categories whereas, e.g., irrigated rice fields are important only for the food category. Thus, forests received the highest score. Moreover, the local population judges forests as important not only because of the products they provide, but also because forests are recognized as a future soil reserve for agricultural food production and are therefore also important for the food category.

The distance from the village to the forest massif has a significant influence on the score for forest fragments $(p=0.011)$ as well as on the score for the forest massif $(p=0.002)$ (Figure 2). In general, people living near the massif seem to be more dependent on natural forests, especially the massif. But they also give a considerable score to fragments, even though the forest massif is very close.

CASH INCOME GENERATION FROM FOREST RESOURCES.

The mean income per household and year generated by timber and NTFPs lies between Euro 1.6 (Maromitety) and Euro 19.7 (Bevalaina). Following the analysis of Rakotoarison (2009), who explored general income generation in the remote villages of the Manompana corridor, cash income from forest products (including NTFPs and timber) comprises only $0.7 \%$ to $9.3 \%$ of the total income that a household generates annually. Compared to other regions of Madagascar's rainforests (Shyamsundar and Kramer 1996), the amounts in our study site are very low. This might be attributed to the lack of access to bigger markets.

Influence by distance: The total cash income from forest products does not differ significantly between either the
TABLE 4. Scores of importance for all landscape types, including all 8 categories of goods and products, separated by village.

\begin{tabular}{|l|c|c|c|c|}
\hline $\begin{array}{l}\text { Landscape } \\
\text { types }\end{array}$ & Ambofampana & Maromitety & Bevalaina & Antsahabe \\
\hline $\begin{array}{l}\text { Walking } \\
\text { hours } \\
\text { to massif }\end{array}$ & $(0.2 \mathrm{~h})$ & $(0.5 \mathrm{~h})$ & $(2 \mathrm{~h})$ & $(3 \mathrm{~h})$ \\
\hline River & 34 & 64 & 42 & 58 \\
\hline $\begin{array}{l}\text { Irrigated } \\
\text { rice } \\
\text { fields }\end{array}$ & 80 & 93 & 70 & 84 \\
\hline Tavy & 150 & 160 & 146 & 115 \\
\hline Savoka & 33 & 20 & 60 & 138 \\
\hline Marsh & 215 & 191 & 94 & 0 \\
\hline $\begin{array}{l}\text { Forest } \\
\text { massif }\end{array}$ & 127 & 118 & 183 & 209 \\
\hline $\begin{array}{l}\text { Forest } \\
\text { fragments }\end{array}$ & 15 & 38 & 22 & 31 \\
\hline Village garden & 59 & 69 & 93 & 93 \\
\hline Tanimboly & 800 & 800 & 800 \\
\hline TOTAL & & & & 72 \\
\hline
\end{tabular}

villages or between the two categories near and far from the forest massif (Figure 3). However, cash income resulting from NTFPS does significantly differ between villages $(p<0.001)$, and between the two categories near and far $(p<0.001)$. The income generated by NTFPs is higher in the two villages close to the massif than those far from the massif. On the one hand, the massif provides better quality and higher amounts of NTFPS than fragments. On the other hand, NTFPs are easier to carry for long distances than timber; thus traders may walk to remote villages to buy NTFPS and vice versa.

The income from logging and timber transport differs significantly between villages near versus far from the massif $(p=0.015)$ due to the distance to the forest massif $(p=0.004)$. Interestingly, farmers living far from the massif have higher incomes from timber than farmers living near the massif.

INFLUENCE BY WEALTH LEVEL. The results in

Figure 3 (right) show a significant relationship between wealth and the total cash income generated from forest products $(p=0.020)$. The difference is significant between poor and intermediate households and between intermediate and

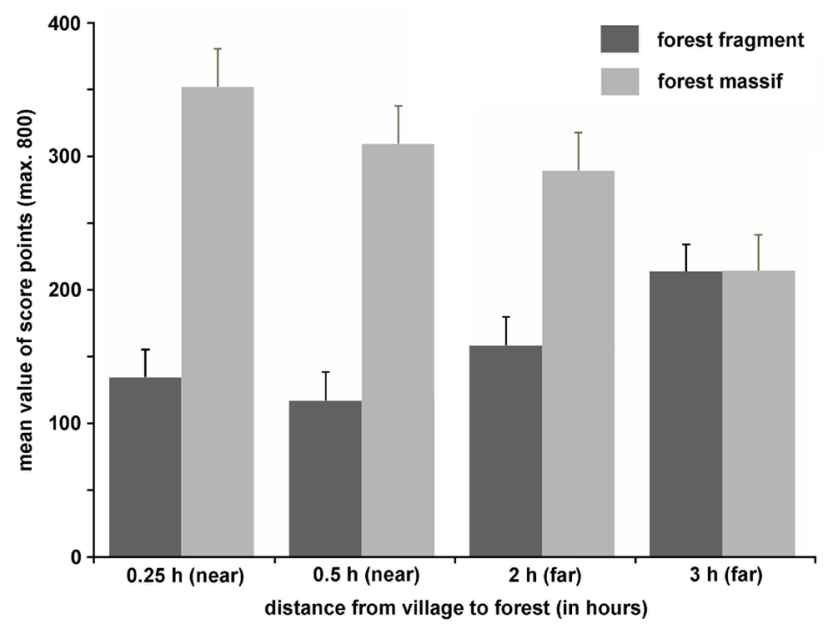

FIGURE 2. Mean values of score points (with standard errors) for the relative judgment of importance for fragment and massif separated by distance to the forest massif. 


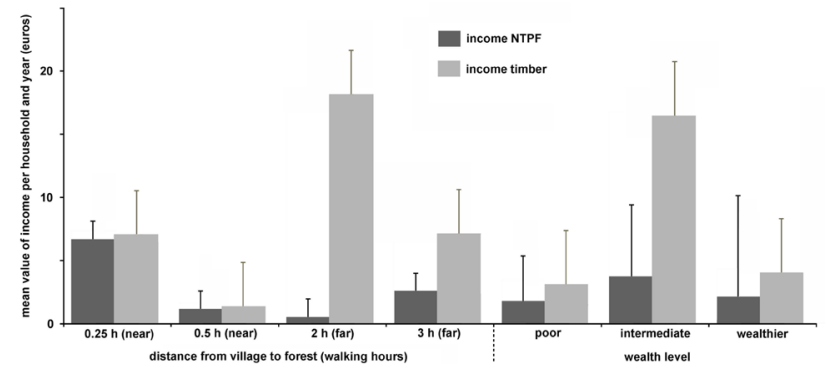

FIGURE 3. Mean cash income per household and year (with standard errors) from timber and NTFP separated by distance to the forest massif (left) and by wealth level (right).

wealthier households. Families with intermediate wealth levels achieve the highest mean income. In this respect, the comparably low income of the poor population class is interesting. With regard to income from timber activities, this can be explained as all of the polled poor farmers work for other families and therefore do not have enough time for additional activities. They also rarely own the necessary instruments to work as loggers. Working as a logger requires a high physical commitment and good health, which members of the poorest households often lack. Nevertheless, in times of shocks and food shortage the poorest are also forced to earn cash by transporting timber. From the questioned poor households, $37 \%$ have an income, although very low, due to transporting activities.

Interestingly, cash income generation does not significantly differ between poor and wealthier groups. Even wealthier households seem to be dependent on cash income from timber. Logging and timber transport activities are mostly performed in times of food scarcity and other crises. Our results indicate the vulnerability of the whole population in our research area, including the wealthier households. Forests can be an important source of income for more than just the poorest households, as has been predicted in other studies (Völker and Waibel 2010).

THE RELATIVE JUDGMENT OF IMPORTANCE FOR NATURAL

FORESTS. In this section we examine how peoples' judgment of the importance of forest fragments and forest massif is influenced by wealth and distance to the forest massif. The values resulting from the scoring exercises include only the income category (see Table 3).

Influence by distance to the forest massif: In the previous section, results showed that the total amount of cash income earned from forest products is not influenced by the distance from the village to the forest massif and does not differ significantly. Likewise, how people judge the importance of natural forests for cash income is not influenced by their distance from the forest. Nevertheless, there is a significant difference in how each village judges all natural forests (forest fragments and forest massif combined) ( $p=0.029)$, forest fragments $(p=0.016)$ and forest massif ( $p=0.016$ ) (Figure 4). People living two walking hours from the massif have a significantly higher income than people living only 0.25 walking hours away. However, the importance score of forests for income is exactly the opposite. The score for importance by local residents reflects a more holistic view, including personal experiences and preferences. We therefore asked the different groups why they scored the importance of forests for income generation as they did. The explanation was that the constant availability of forest products is fundamental to them and equal to the importance of income quantity. Products from natural forests are always available and, although to limited extent, tradable. This is a crucial characteristic of forest resources in times of shocks and periods of rice shortage.

The difference for the importance of fragments and massif also differs between villages $(p=0.016$ and $p=0.016)$ and between the two categories near and far $(p=0.007)$. Farther away from the forest massif, the importance score is higher for forest fragments and lower for the massif.

Influence by wealth level: For all natural forests, forest fragments and forest massif, results showed no significant difference between wealth levels (Figure 4, right). However, it is surprising that the poorest households, which have the lowest cash income generation from forest products (see Figure 3), give the highest score to the importance of all forests for cash income. Households of the intermediate class, which generate considerably more income through forest products than do the other wealth classes, do not place more importance on the forest than do the other wealth levels.

INTEREST IN CONSERVING FOREST FRAGMENTS.

The interest of the different population groups in preserving forest fragments was analyzed by means of specific research questions, such as "for what reason did you conserve your fragment until this day?" This question was asked of all families that were, according to local custom (Razafy 2004, Muttenzer 2010, Urech et al. 2011), owners of forest fragments $(N=50)$. The main answers given by the forest fragment owners concerned either the benefit of the forest for timber and NTFPS, or its role as a soil reserve for future descendants (Pfund 2000, Keller 2008). If farmers see forest fragments as important only as a soil reserve, we assume no long-lasting interest in preserving it. Sooner or later the fragment will be converted into arable land for the family. Interpreting the answer that fragments are important for timber and NTFP, we assume an existing awareness about the finite and predictable supply of the resource and therefore an interest in preserving it. Of course this answer is no guarantee that the family will continue to conserve its fragments, but it demonstrates that there is a certain interest in preserving forests.

Influence by distance: Most farmers living close to the forest massif still believe that forests are not exhaustible and therefore must not be protected because "there will always be forest". However, there is a significant correlation between distance (to the massif) and farmer responses ( $\chi^{2}=19.924, \mathrm{df}=6, \varrho=0.003$ ). We infer that the further the population lives from the massif, the more interest it has in conserving the forest (Figure 5). Farmers living far from the forest massif already experienced a fundamental decrease in forest surface and thus, forest resources.

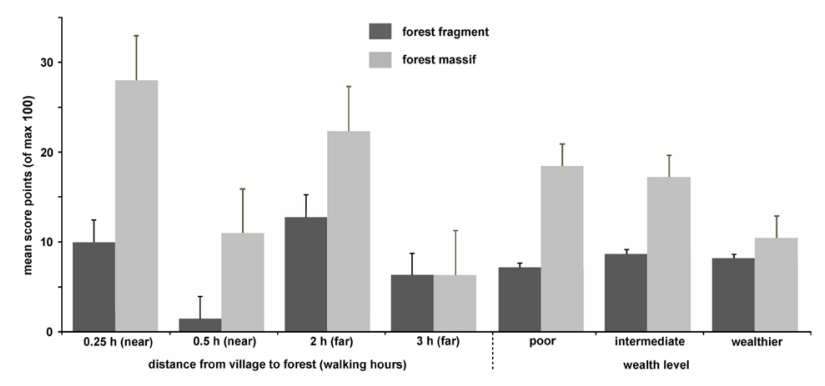

FIGURE 4. Mean value of score points (with standard errors) for the relative judgment of importance of fragment and massif for the income category separated by distance to the forest massif (left) and by wealth level (right). 
They are aware, that the last remaining forest fragments may disappear as well if they are not protected in future.

Influence by wealth: The correlation between wealth level and response is also significant $\left(\chi^{2}=14.375, \mathrm{df}=4, \mathrm{Q}=0.006\right)$ (Figure 5). The wealthier the population is, the more interest it has in preserving forest fragments for timber and NTFPS. Wealthier households in general have more land than poor farmers, higher crop diversity and more alternatives to generate cash income, thus they are less dependent on slash-and-burn cultivation systems to plant crops and to gain more arable land.

\section{DISCUSSION}

MEASURING IMPORTANCE. The importance of forests in

local livelihood systems includes different facets. Scoring exercises for eight categories of goods and products show that forests play a role in almost all categories. But most of these products can be replaced by products coming from other landscape types without having significant impact on local wealth (unpubl. data). Fuel wood can be collected in agroforestry systems, medicinal plants are replaced from swamps or secondary vegetation. However, income generated from forest products (timber and NTFPS) can hardly be replaced, as possibilities for alternative income generation are scarce. Therefore, cash income from forest products seems to be a good indicator to measure how depending on forest resources people really are.

Using the single metric of economic importance, this article shows the very complex reasons that influence how the local population judges the importance of natural forests to generate cash income. Importance can be measured with quantitative information resulting from income surveys or scoring exercises. However, to develop reliable reasons and explanations for the given quantitative information, the data must be evaluated in the context of peoples' livelihoods (lean seasons, individual wealth and health, knowledge, etc). Our results show that income generated from forest products is very low if compared with other regions. Although very low, it is nonetheless of importance. Especially during the lean-season, the availability of NTFPs and timber as commodity can always be assured. However, our results showed as well that even though natural forests offer considerable opportunities for income in some cases, they are rated as more important by people who do not necessarily benefit much from them. A very low income can be of high importance during a lean period, especially in case of a household's high vulnerability. We therefore conclude that the importance of forests for local residents is not only related to the quantitative opportunities arising from forests, but also to local livelihood systems and strategies. Other factors, such as

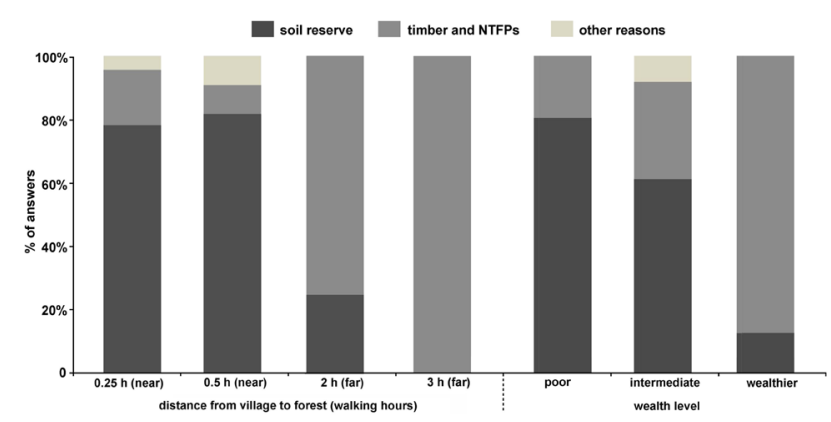

FIGURE 5. Reasons for forest fragment conservation, separated by distance to the forest massif (left) and by wealth level (right). the possibility to generate cash income through other landscape types or alternative activities, could influence people's perception of the importance of a cash income from forest products. Moreover, wealthier households generally produce enough crops for personal consumption, while poor households are forced to buy food during the lean period and are therefore more dependent on alternative sources of income.

In our study site, people make a clear differentiation between the importance of the forest massif and forest fragments. Even in villages close to the forest massif, forest fragments have a fundamental value. This can be explained by the fact that, following the local customary rights, forest fragments have a recognized traditional 'owner' (Urech et al. 2011); thus, forest fragments are valued for their soil reserves. Moreover, families prefer to collect particular products in their own forest fragments next to the rice fields instead of the forest massif. This distinction between fragments and massif becomes even more important with increasing distance to the forest massif, where only forest fragments remain to satisfy local peoples' daily needs, especially the generation of income. Thus, we recommend that the different understandings of forest massif and forest fragment must be integrated into future forest management.

THE INFLUENCE OF DEPENDENCY ON CONSERVATION

INTERESTS. At the outset we introduced Gibson's (2001) hypothesis that people who depend on forest resources have more interest in conserving them. Categorizing people by the distance from the village they are living in to the forest massif, results show that people judge forest resources significantly more important the closer they live to the forest massif. This can be explained if one considers the livelihood context of the people living near the massif. Firstly, households close to the massif have fewer alternative possibilities for generating income because they are situated in a very remote and inaccessible area. Secondly, they are also more vulnerable to natural disasters such as cyclones, which increase the dependency on forest resources. Nevertheless, the concerned households are not interested in preserving forest fragments for NTFPs or timber products that could be sold or used for personal consumption. Rather, villagers close to the forest massif consider forest fragments as soil reserves for the future. This is not surprising as farmers depend much more on agriculture than natural forests. Conversely, the majority of people far from the forest massif seem to be much more interested in preserving forest fragments for NTFPs and timber, even though they do not significantly rely more on income from forest products and judge the overall importance of natural forests with lower scores than villagers close to the forest massif. We therefore cannot confirm the hypothesis that peoples' dependency influences their interest in conserving forests (cf. Gibson 2001) in our research area.

Possibly the variable of proximity to markets has the higher influence on how much interest people have to conserve their remaining forest resources. Timber is much more tradable far from the massif where resources are scarce and population density is high. Additionally, farmers do not have to walk very far to sell their timber, while people living close to the forest massif have to walk up to eight hours, carrying timber planks on their shoulder and traverse landscapes that are often steep and hilly or swampy. Therefore, people close to the forest massif seem to be more dependent on cash income from forest products, 
but do not perceive for example timber to have high potential for income generation. Meanwhile, people far from the forest massif and close to the markets see the important potential of the remaining forest fragments containing still high amount of precious woods (Rakotomavo 2009). We can therefore conclude that forest fragments are currently of greater importance for timber trade than the forest massif.

considering different wealth levels, we concur with Gibson (2001) that dependency does not precipitate conservation. Wealthier households gain little income from forest products, but how such households score the importance of forests does not differ significantly from the two other wealth categories. Nonetheless, wealthier families have significantly more interest in preserving forest fragments for timber and NTFPS. Additionally, $78 \%$ of the wealthier households want an end to the system of slash-and-burn for the whole village, even though they are not very dependent on forest products. We therefore reason that dependency on the forest does not have much influence on conservation interest in our study site. We have to point out that in this article we only refer to dependency with regards to income. Dependency on forests includes much more than just income (e.g., medicinal plants, food, material for house construction, fuel wood, etc.). Nonetheless, we think that cash income represents very well the difference between households, as most other products are collected by all households independently of wealth or distance to the massif. Likewise, environmental services are important for all households equally, as all families depend on water provision and agricultural production.

THE INFLUENCE OF RESOURCE SCARCITY ON

CONSERVATION INTERESTS. In exploring the hypothesis that resource scarcity enhances interest in forest preservation (Behera 2009, Wu and Mweemba 2010), we find more coherence in our study site. Villagers living far from the forest massif and thus living in landscapes with only forest fragments remaining seem to be aware of resource scarcity and finality. In the village the farthest from the forest massif, $100 \%$ of the villagers conserved their remaining forest fragments because of the need for NTFPs and timber. People are aware that this need cannot be fulfilled if forests are converted for agriculture. As noted earlier, while this awareness and interest is no guarantee that villagers will continue to conserve forest fragments, it does at least demonstrate an awareness that does not exist in villages close to the forest massif. This fact has to be considered in future management activities, as former studies have shown that the more individuals are aware of the degradation of the environment and its consequences, the more likely they will try to ameliorate the situation (Wu and Mweemba 2010). Additionally, greater environmental awareness leads to greater involvement in resource management programs (Wu and Mweemba 2010).

\section{CONCLUSION}

We conclude that with regard to our study site, one of the hypotheses introduced in the introduction can be affirmed and the other must be rejected. The two categories of population groups in the Manompana corridor which are the most interested in conserving forest fragments are: the wealthier households that are less dependent on forest resources; and families living far from the forest massif which are aware about the resource scarcity. It has to be pointed out that this conflicting interest in resource conservation within one community-based forest management area can be an important source of social conflict between the concerned villages. Therefore, we suggest assuring an equal involvement and participation of villages far and villages close to the massif in future forest management. A formal structure of governance is required which would communicate and resolve conflicts between different interest groups and villages in order to integrate differing needs. The involvement of villages far from the massif has the advantage that residents far from the massif have a greater awareness of resource scarcity and thus greater interest in involvement in resource management. However, farmers living close to the forest should also be involved in the decision-making process as most of the forest area lies within their traditional village territory.

Furthermore, the difference between forest fragments and forest massif with regards to their importance and customary rights should be respected in future management plans. For local peoples' livelihoods, the value of forest fragments increases with distance from the massif to where the villages are situated, as natural forests are becoming scarce. Moreover, because forest fragments are traditionally owned by families they play a significant role for families' land reserve, more than the forest massif. If elaborating a forest management plan, these differences must be considered in order to meet local interests and to respect customary understanding of forest ownership.

Another point is that the poorest households currently earn a very limited income from forest products. Only a few of the poorest people work as loggers because most lack the knowledge, instruments and health to do so. If future forest management is to reduce poverty by increasing local people's participation in the trade and management of forest products, the involvement of the poorest households should be greatly improved.

\section{ACKNOWLEDGMENT}

We would like to thank the organizations that have helped to fund our research. This research project has been supported by the Research Fellow Partnership Program (RFPP) of the NorthSouth Center at the ETH Zurich and the Commission for Research Partnership with Developing Countries (KFPE), both financed by the Swiss Agency for Development and Cooperation (SDC). Furthermore we thank the local population of the Manompana Corridor, the KoloAla project, AIM (Association Intercooperation Madagascar), the reviewers for constructive contributions, and Erin Gleeson for her very helpful comments and English corrections.

\section{REFERENCES}

Barham, B. L., Coomes, O. T. and Takasaki, Y. 1999. Rain forest livelihoods: income generation, household wealth and forest use. Unasylva 50, 3: 34-43.

Bawa, K. S., Joseph, G. and Setty, S. 2007. Poverty, biodiversity and institutions in forest-agriculture ecotones in the western Ghats and eastern Himalaya ranges of India. Agricultural Ecosystems \& Environment 121, 3: 287-295. (doi:10.1016/j.agee.2006.12.023)

Behera, B. 2009. Explaining the performance of state-community joint forest management in India. Ecological Economics 69, 1: 177-185. (doi:10.1016/j.ecolecon.2009.08.015)

Bertrand, A., Montagne, P., Besse, F., Serre-Duhem, C. and Raharimaniraka, L. 2006. Nouvelle politiques forestières et gestion économique publique des filières des produits forestiers non ligneux. In: Forêt Tropicales et Mondialisation. Les Mutations des Politiques Forestières en Afrique Francophone et à Madagascar. A. Betrand, P. Montagne and A. Karsenty (eds.), pp 243-275. L'Harmattan. 
Carter, J. 2008. Project Kolo Ala Manompana: Mission report. Adressing vulnerability in project activities. Bern.

Dubois, O. 2003. Forest-based poverty reduction: a brief review of facts, figures, challenges and possible ways forward. In: Forests in Poverty Reduction Strategies: Capturing the Potential. T. Oksanen, B. Pajari and T. Tuomasjukka (eds.) pp 65-81. European Forest Institute, Joensuu, Finland.

Fedele, G., Urech, Z. L., Rehnus, M. and Sorg, J.-P. 2011. Impact of women's harvest practices on Pandanus guillaumetii in Madagascar's lowland rainforests. Economic Botany 65, 2: 158-168. (doi:10.1007/s12231-0119157-0)

Gaemperli, U. 1997. L'organisation du travail dans le fokontany d'Avaratrambolo. Cahiers Terre-Tany Antanananarivo.

Gibson, C. C. 2001. Forest resources: Institutions for local governance in Guatemala. In: Protecting the Commons: A Framework for Natural Resource Management in the Americas. E. Burger, E. Ostrom, R. B. Norgaard, D. Plicansky and B. D. Goldstein (eds.) pp 71-90. Island Press, Washington, D.C.

Gorenflo, L. J., Corson, C., Chomitz, K. M., Harper, G., Honzák, M. and Özler B. 2011. Exploring the association between people and deforestation in Madagascar. Human Population 1650, 2: 197-221. (doi:10.1007/9783-642-16707-2_11)

Harper, G. J., Steininger, M. K., Tucker, C. J., Juhn, D. and Hawkins, F. 2007. Fifty years of deforestation and forest fragmentation in Madagascar. Environmental Conservation 34, 4: 325-333. (doi:10.1017/ S0376892907004262)

Keller, E. 2008. The banana plant and the moon: Conservation and the Malagasy ethos of life in Masoala, Madagascar. American Ethnologist 35, 4: 650-664. (doi:10.1111/j.1548-1425.2008.00103.x)

Laurance, W. F., Laurance, S. G. and Delamonica, P. 1998. Tropical forest fragmentation and greenhouse gas emissions. Forest Ecology and Management 110, 1-3: 173-180. (doi:10.1016/S0378-1127(98)00291-6)

Laurance, W. F., Lovejoy, T. E., Vasconcelos, H. L., Bruna, E. M., Didham, R. K., Stouffer, P. C., Gascon, C. Bierregaard, R. O., Laurance, S. G. and Sampaio, E. 2002. Ecosystem decay of Amazonian forest fragments: a 22 years investigation. Conservation Biology 16, 3: 605-618. (doi:10.1046/j.1523-1739.2002.01025.x)

Legout, A., Walter, C. and Nys, C. 2008. Spatial variability of nutrient stocks in the humus and soils of a forest massif (Fougères, France). Annals of Forest Science 65, 1: 108-118. (doi:10.1051/forest:2007080)

Malanson, G. P. and Armstrong, M. P. 1996. Dispersal probability and forest diversity in a fragmented landscape. Ecological Modelling 87, 1-3: 91-102. (doi:10.1016/0304-3800(94)00202-9)

Martin, P. 2008. Influence de la fragmentation forestière sur la régénération des espèces arborées dans le sud-Ouest de la Côte d'Ivoire. Unpubl. Ph.D. thesis. Université de Genève, Genève.

Messerli, P. 2002. Alternatives à la Culture Sur Brûlis sur la Falaise Est de Madagascar. Stratégie en vue d'une gestion plus durable des terres. Unpubl. Ph.D. thesis. Université de Berne, Berne.

Minten, B. and Barrett, C. B. 2008. Agricultural technology, productivity, and poverty in Madagascar. World Development 36, 5: 797-822. (doi:10.1016/j.worlddev.2007.05.004)

Moat, J. and Smith, P. 2007. Atlas of the Vegetation of Madagascar. Royal Botanic Gardens, Kew.

Muttenzer, F. 2010. Déforestation et Droit Coutumier à Madagascar. Les Perceptions des Acteurs de la Gestion Communautaire des Forêts. Karthala, Institut de Hautes Études Internationales et du Développement, Paris, Genève.

ODEM. 2005. Méthodologie de Définition des Massif Forestiers. Observatoire Département de l'Environnement du Morbihan.

Ormsby, A. and Kaplin, B. A. 2005. A framework for understanding community resident perceptions of Masoala National Park, Madagascar. Environmental Conservation 32, 2: 156-164. (doi:10.1017/ S0376892905002146)

Ostrom, E. 1999. Self-governance and Forest Resources. Occasional Paper No 20. CIFOR, Jakarta, Indonesia.

Pfund, J.-L. 2000. Culture Sur Brûlis et Gestion des Ressources Naturelles. Evolution et Perspectives de Trois Terroirs Ruraux du Versant Est de Madagascar. ETH Zurich and EPFZ Lausanne, Zurich.
Pfund, J.-L., O'Connor, T., Koponen, P. and Boffa, J.-M. 2006. Transdisciplinary Research to Promote Biodiversity Conservation and Enhanced Management of Tropical Landscape Mosaics. IUFRO Landscape Ecology Conference, Italy.

Pfund, J.-L., Watts, J. D., Boissière, M., Boucard, A., Bullock, R. M., Ekadinata, A., Dewi, S., Feintrenie, L., Levang, P., Rantala, S., Sheil, D., Sunderland, T. C. H. and Urech, Z. L. 2011. Understanding and integrating local perceptions of trees and forests into incentives for sustainable landscape management. Environmental Management 48, 2: 334-349. (doi:10.1007/s00267-011-9689-1)

Pollini, J. 2009. Agroforestry and the search for alternatives to slash-andburn cultivation: From technological optimism to a political economy of deforestation. Agriculture, Ecosystems \& Environment 133, 1-2: 48-60. (doi:10.1016/j.agee.2009.05.002)

Rabenilalana, M. 2011. Fragmentation et Dynamique du Paysage de la Forêt Dense Humide de Basse Altitude. Cas de Manompana - Nord-Est de Madagascar. Unpubl. Ph.D. thesis. Université d'Antananarivo, Antananarivo.

Rabenilalana, M., L. G. Rajoelison, J.-P. Sorg, J.-L. Pfund, and H. Rakoto Ratsimba. 2010. Multi-temporal analysis of forest landscape fragmentation in the north east of Madagascar. In: Forest Landscapes and Global Change. New Frontiers in Management, Conservation and Restoration. J. C. Azevedo, M. Feliciano, J. Castro and M. A. Pinto (eds.) pp 91. Proceedings. IUFRO, Bragança, Portugal.

Rakotomavo, A. 2009. Schéma d'aménagement du site KoloAla Manompana. Report, AIM, Union Européenne, Manompana.

Ranta, P., Blom, T., Niemela, J., Joensuu, E. and Siitonen, M. 1998. The fragmented Atlantic rain forest of Brazil: size, shape and distribution of forest fragments. Biodiversity and Conservation 7, 3: 385-403. (doi:10.1023/A:1008885813543)

Razafy, F. L. 2004. Les intérêts des différentes acteurs dans la gestion des ressources naturelles forestières. Schweizerische Zeitschrift für Forstwesen 155: 89-96.

Rustagi, D., Engel, S., and Kosfeld, M. 2010. Conditional cooperation and costly monitoring explain success in forest commons management. Science 330, 6006: 961-965. (doi:10.1126/science.1193649)

Schmidt, K. 2007. Livelihoods and Forest Management in Transition Knowledge and Strategies of Local People in the Walnut-Fruit Forests of Kyrgyzstan. Unpubl. Ph.D. thesis. University of Reading, Reading.

Sheil, D. and Liswanti, N. 2006. Scoring the importance of tropical forest landscapes with local People: Patterns and Insights. Environmental Management 38, 1: 126-136. (doi:10.1007/s00267-005-0092-7)

Sheil, D., Puri, R. K., Basuki, I., van Heist, M., Wan, M., Liswanti, N., Rukimiyati, Sardjono, M. A., Samsoedin, I., Sidiyasa, K., Chrisandini, Permana, E., Angi, E. M., Gatzweiler, F., Johnson, B. and Wijaya, A. 2002. Exploring Biological Diversity, Environment and Local People's Perspectives in Forest Landscapes. Methods for a Multidisciplinary Landscape Assessment. CIFOR, Jakarta, Indonesia.

Sheil, D., Puri, R., Wan, M., Basuki, I., van Heist, M., Liswanti, N., Rukmiyati, Rachmatika, I. and Samsoedin, I. 2006. Recognizing local people's priorities for tropical forest biodiversity. Ambio 35, 1: 17-24. (doi:10.1579/0044-7447-35.1.17)

Shvidenko, A., Jorgensen, S. E. and Fath, B. 2008. Deforestation. In: Encyclopedia of Ecology. S. E. Jorgensen and B. D. Fath (eds.) pp 853-859. Academic Press, Oxford.

Shyamsundar, P. and Kramer, R.A. 1996. Tropical Forest Protection: An empirical analysis of the costs borne by local people. Journal of Environmental Economics and Management 31, 2: 129-144.

Tumusiime, D. M., Vedeld, P. and Gombya-Ssembajjwe, W. 2011. Breaking the law? Illegal livelihoods from a Protected Area in Uganda. Forest Policy and Economics 13, 4: 273-283. (doi:10.1016/j.forpol.2011.02.001)

Urech, Z. L., Rabenilalana, M., Sorg, J.-P. and Felber, H. R. 2011. Traditional use of forest fragments in Manompana, Madagascar. In: Collaborative Governance of Tropical Landscapes. C. J. P. Colfer and J.-L. Pfund (eds.), pp 131-155. Earthscan, London and Washington D.C.

USAID. 2009. For a sound management of forest resources. Outcomes of 5 years of work. USAID.

Völker, M. and Waibel, H. 2010. Do rural households extract more forest products in times of crisis? Evidence from the mountainous uplands of Vietnam. Forest Policy and Economics 12, 6: 407-414. (doi:10.1016/j. forpol.2010.03.001) 
Wu, H. and Mweemba, L. 2010. Environmental self-efficacy, attitude and behavior among small scale farmers in Zambia. Environment, Development and Sustainability 12, 5: 727-744. (doi:10.1007/s10668009-9221-4)

Wunder, S. 2001. Poverty alleviation and tropical forests - what scope for synergies? World Development 29, 11: 1817-1833. (doi:10.1016/S0305750X(01)00070-5) 